\title{
Teaching languages online: Deconstructing the myths
}

\author{
Uschi Felix \\ Monash University
}

Debates on e-learning often begin by comparing apples with oranges. The 'theatre of the classroom' and the rich social tapestry of the campus are contrasted with a barren, solitary, inhuman online experience consisting of no more than downloading texts and submitting assignments. While the comparison ensures amusing entertainment, it does no more than claim that a piece of technology cannot replicate or even simulate what a brilliant teacher can do in a classroom. Of course it cannot. What is more, without the intervention of a creative teacher, the Web and the Internet can at best function as a convenient materials resource and communication vehicle.

This paper will take a critical look at popular myths attached to online learning from three perspectives: administrators, teachers and students. The central questions underpinning the discussion as a whole are (1) why would we want to teach online? (2) what are the constraints? and (3) how can we do it well despite the constraints?

The paper argues that the exciting promise of the new technologies is that they offer an environment in which an innovative teacher can set up authentic learning tasks in which both the processes and the goals are stimulating and engaging, and which take individual student differences into account. It will demonstrate by way of practical examples that the new technologies offer great potential for adding value to face to face teaching and that the greatest challenge lies in designing and sustaining quality language programs at a distance.

\section{Introduction}

The rhetoric about online learning has changed significantly over the last few years, as players have gained practical experience at all levels. Initial euphoria about the brave new world that technology was opening up led many institutions to launch into hasty and expensive developments, not just because of the giddy promises, but also for fear of missing the boat. A reaction was perhaps inevitable, with the most savage critics accusing the institutions of turning themselves into 'digital diploma mills' (Noble, 1997, 
1998a, 1998b). However, the more extreme criticisms were no more realistic than the more extreme hopes, and increasingly commentators have begun to take a more measured look at the potential of online learning, and to emphasise the importance of sound online pedagogy. One - perhaps surprising - result of the debate is that online teaching and learning is being more closely scrutinised than classroom teaching ever was. However, the debate is still dominated by a galore of generalised, unqualified statements and the most common myths appear to be the following:

- Administrators are interested only in saving costs and have little interest in the quality of any learning that is taking place.

- Online learning will replace classroom teaching.

- Teaching online will save time.

- Offering courses online will save staff.

- Students resent being taught online.

- It is not possible to teach as well online as in the classroom.

Such criticisms and promises, in fact, are rather mild and measured by comparison with the gratuitous Web-bashing that is also seen quite frequently in newspaper columns: 'If online learning is so clever, why not let the laptop do the learning?' (Mackay, 2001). There is nothing wrong with subjecting all forms of online learning to quality analysis - quite the contrary - but we should also be aware of the unhelpful and unjust lopsidedness of an analysis that does not subject traditional classroom teaching to the same scrutiny. The objective for all forms of teaching and learning must be to monitor the quality of what is being done.

In spite of all this, some institutions seem to be thriving and some courses seem to be very successful in attracting online students. What is more, the literature is reporting ever larger numbers of innovative and exciting online activities. This disparity raises the inevitable question: What really is happening in the field and what is the true state of affairs? One of the problems that has to be faced is the memory of bad implementations from five years ago, which continues to exercise a strong negative influence despite recent advances in the field.

Another is that it is rare for anybody to take a comprehensive look at the whole picture. It is more common for separate consideration to be given to individual groups like administrators, teachers and students, with the result that no consolidated picture ever emerges. In fact, though, while different groups might well have different goals, some needs are common to all.

Comprehensive analysis is not helped by the massive ambiguities apparent whenever online learning is discussed. The lack of definition 
means that it is not always clear what is being criticised or hailed as a panacea. Fully online learning? Distance courses like those offered by the Open Universities or some large commercial operations? Add-ons to face to face teaching? There are, after all, likely to be large differences in perceptions between highly motivated non-traditional students who have enrolled in online courses by choice, and traditional students in a regular classroom who are offered some online activities as a replacement for costly tutorials.

This paper will throw light on the confusion by attempting a definition of online learning and taking a critical look at the six popular myths above from the perspectives of administrators, teachers and students. The central questions underpinning the general discussion are: (1) why would we want to teach online; (2) what are the constraints; and (3) how can we do it well? The answers will quickly reveal three major points. Firstly, there are persuasive reasons for using online technologies both as valuable extensions to what can be done in the classroom and for improving the quality of traditional distance education, especially if we believe in constructivist approaches. Secondly, while the constraints have become less severe over recent years, some are still pervasive and cannot be ignored. Lastly, and perhaps most importantly, it will emerge that the better we want to teach online, the more we need to consider the resources in terms of time and money that may be required.

In languages we have advantage and disadvantage on our side. To teach a language fully online requires even more resources and effort than to teach other subjects in the humanities. By the same token, we have been grappling for longer than any other discipline with the need for interactivity and communication and with ways of engaging the learner in real life activities and authentic settings. Surely we have experimented long enough with technologies to step back and take a realistic look at what we might be able to do within the constraints in which most of us find ourselves in times where both money and time are at a premium. One of the goals of this paper is to do just that.

\section{Defining the impossible}

Giving a clear definition of what might be meant by online learning is as difficult as trying to herd cats. There are as many different approaches as there are nomenclatures and learning theories (Felix, 2001), and the task is not made easier by a lack of congruity between learning theory and teaching practice (Goodyear, 2002). This in itself is no different from classroom learning, but we now have to deal with the added complication of the role of technology in the process. 
Generally it can be said that there are two major forms of online learning. On the one hand there are stand alone online courses that strive to operate as virtual classrooms, in which the technology acts both as tutor and tool. High quality examples are still very rare in languages. On the other hand there are add-on activities to classroom teaching or distance education courses in which technology is used primarily as a tool and communication device. Teachers are present to varying degrees in both forms, and either can be excellent or poor, just as classroom teaching does not hold an automatic monopoly on best practice education.

The most important consideration in any model is the distinction between delivering content and creating connectivity (Felix, 2002). If all we offer online are course materials and activities in the form of drill and practice, then the harsh criticisms of bad quality teaching are well deserved and we will not have advanced from the mistakes we made in the language laboratory and early CD-ROM eras. With the wisdom of hindsight, though, the picture is changing and the best current approaches are driven by sound pedagogical considerations. In these the technology is being used as a tool and the objective is to create learning environments in which a creative teacher can set up authentic learning tasks, in which both the processes and the goals are stimulating and engaging, and which take individual student differences into account. This is far removed from Noble's justified criticism of the content driven, technology as tutor, 'computer -replacing the teacher' model (Noble, 2001):

...the core of my argument is that education is essentially an interpersonal and I'm not saying interactive - an interpersonal affair and the substitution of machinery as a mediation ultimately leads to an interruption of that interpersonal interaction.

The issue of quality has a large part to play in distinguishing between justified and gratuitous criticisms. There are few players left to defend poor quality online ventures since students are discerning enough to express their needs by not enrolling in them. Successful online institutions such as the University of Phoenix Online have demonstrated the value of starting from a best practice teaching approach as well as adding some face to face contact (White \& Weight, 2000).

We now see that our success was founded on how well faculty members were able to adapt the technology in order to connect with students and to create meaning from the human - rather than the technological connection...We used the technology as a tool to enable human relationships to form and interactive learning to occur. (White \& Bishop, 2000:185)

The value of a physical environment is another contentious issue. While no one would question the regular classroom and campus setting as a 
potentially rich and nurturing environment in which learning occurs both formally and serendipitously, how confident can we be these days that these environments will meet the ideal requirements? Even where technology is not involved, we already hear enough complaints about poor learning conditions, such as, to name only the most common, cuts in teaching staff, overcrowded lecture theatres and minimal feedback. Naturally it was tempting to think that technology could make a significant contribution to overcoming these problems.

\section{The reasons for going online: Chasing the promise}

The Web and the Internet offered administrators real alternatives for delivering courses in which savings might be made in space and staff, access to education improved, and enrolments increased. The 'not missing the boat' rationale added its own momentum in the drive to have an online presence as quickly as possible.

For teachers the attractions were largely of a different nature. As with previous technologies, language

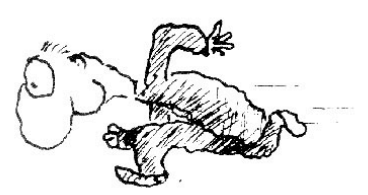
teachers in particular were tempted

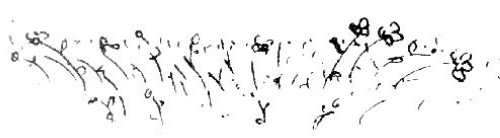
by the possibility of redistributing time, by transferring part of the core business such as the learning of grammar and vocabulary, to the computer and using class time for more communicative activities. More importantly, though, they quickly discovered the potential of the Web and the Internet as a window to the authentic world of the languages being taught, allowing for interaction and communication far richer than hitherto possible. Task based projects, ranging from simple Web searches in target language sites to large collaborative ventures in virtual worlds, added enormous potential to the repertoire of dedicated language teachers.

The greatest attraction for students to engage with online learning was the flexibility of time and space that it offered. They also valued the wide scope of learning opportunities that good quality courses could provide, especially the wealth of information and resources that might be found in one place, including instant quality feedback, accessible from their home computer as well as instantaneous access to their tutor.

It does not take a great deal of analysis to discover where these perspectives have failed to converge and which of the great expectations 
have been turned into myths. If we take a look at the constraints faced by the same three groups, an even clearer picture emerges.

\section{The constraints of online learning: Hitting the wall}

Administrators realised very quickly that cost savings (Myth 1) were indeed only possible if poor alternatives to face to face courses were offered. Even then the infrastructure costs were high and the low uptake by largely recalcitrant staff hardly justified the capital outlay. While institutions' fears about missing the boat in terms of attracting students who might otherwise go elsewhere may

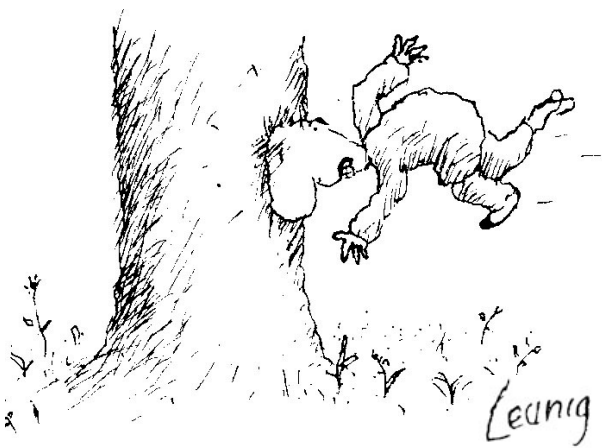
have been justified, they could not afford to allow their reputations to be damaged by dubious online ventures and poor quality outcomes. The rhetoric steadily shifted towards seeing online learning as an addition to a rich educational experience rather than its replacement (Myth 2). With this had to come a commitment to a first class infrastructure, including broadband access and the provision of training and support in both IT and pedagogy, site licences for course tools, administrative support, and time release for staff engaged heavily in developing materials (see Cho \& Berge, 2002 for a discussion of overcoming barriers to distance education). In this context it makes sense that institutions experienced in online teaching should charge higher fees for courses offered fully online and that administrators should restrict their expectations of cost savings to the element of space (Tuovinin, 2001). The real costs of providing this sort of learning are difficult to estimate and even rigorous, activity based costing is bound to overlook the many hours of unrecorded staff time involved in the process (Bacsich et al, 2001).

This last point is precisely what even the most enthusiastic teachers continue to experience as one of three serious constraints. First, not only is the production of good quality materials very time consuming, but monitoring students' contribution to discussion groups, organising cooperative activities and answering student email queries can became overwhelming for many teachers, however dedicated (Nelson \& Oliver, 1999, Brabazon, 2001, Morgan, 2001, Rocklin, 2001). In a climate where educators in all sectors are dealing with increasing amounts of bureaucracy, it is difficult to find the large number of extra hours that are 
required to do the task well, let alone save time (Myth 3) or, more ludicrous still, save staff (Myth 4).

Secondly, many teachers still lack sufficient expertise in IT, and in most environments do not have adequate support structures (see The Campus Computing Project, 1999). The situation is not helped by the fact that technological developments move too fast for teachers to keep up, and in many cases it would be more desirable if technologies were built to suit teachers' skills rather than the other way around (Stott, 1999).

The experience of learning technology practitioners over the last twentyfive years has been rather like climbing a mountain. A peak appears in sight but when it is reached it turns out to have been just a foothill and a higher peak becomes visible. When this is reached however the new vista reveals a further higher peak, and this process appears to continue almost indefinitely (Darby, 2002:2).

The continual frustrations faced by teachers, when technology fails more often than not, often make them give up completely. If current IT resources were as user-friendly as audio- and video-tapes have been, takeup of technology in language classrooms would be much higher than it currently is. In an article aptly entitled 'Computing the costs in dollars and stress', Walker (2002:9) makes the same observation about the home front that many teachers have long felt in the classroom:

Some days, the landscape of home computing looks like one long vista of compromises, half-fixes, broken promises and unfulfilled potential.

Lastly, access to technology and broadband connections varies tremendously between individual institutions and countries. Even though conditions have improved a great deal over the last two years, especially in Northern Europe and South East Asia (Kirkman, 2002), there are still frequent reports of teachers and students complaining about access problems (Zähner et al, 2000, Davies, 2002).

For students this can mean more than simply getting online. In order to participate fully and comfortably in this form of learning, they are now faced with the costs of providing state of the art computers and broadband access. They are also invariably left to foot the bill for printing - another item that may go unnoticed in estimating the costs of online learning (Bacsich et al, 2001). In addition, they may not have all the IT skills required to function adequately in an online environment, especially if they are mature age students (Felix, 2001, Hargittai, 2002) and are equally frustrated by malfunctioning IT (Hara \& Kling, 1999). Younger students may also not possess the meta-skills necessary to cope with a predominantly student centred approach to learning (Schank \& Cleave, 1995:178). 
...how can students learn by doing what they do, when they do not know how to do what they have to do to learn?

As in previous distance learning environments, some students still report feelings of isolation and problems with motivation (Morgan, 2001). These complaints are more likely in courses in which content dominates over connectivity, although we need to keep in mind that the provision of communication facilities alone will not address these problems adequately (Berge, 1995, Salmon, 2000). For language students in particular, the absence of real speaking opportunities online and the limited feedback that still dominates in current offerings are seen as very serious constraints (Felix, 2001).

While students who persevere with online courses which they have chosen voluntarily usually cope well even with poor quality offerings, outright resentment can be seen where students have been forced into online ventures. This resentment is sometimes expressed even in the absence of any personal experience, reflecting the negative rhetoric about online learning. There is some evidence that students presented with the choice of several modes of learning tend to judge what they are currently involved in as the best option (Felix, 2000, 2001) and that online learning is more likely to be adopted by nontraditional students: older students, students with spouses or with children at home and students working longer hours (De Ferrari et al, 1998).

\section{Gathering thought}

The discussion so far appears to lead us to the conclusion that it may be just too hard to engage in language teaching online. To add to the uncertainty, we do not have any real evidence of the educational outcomes of online ventures, espec-ially not as measured against capital outlay. The bulk of the literature on

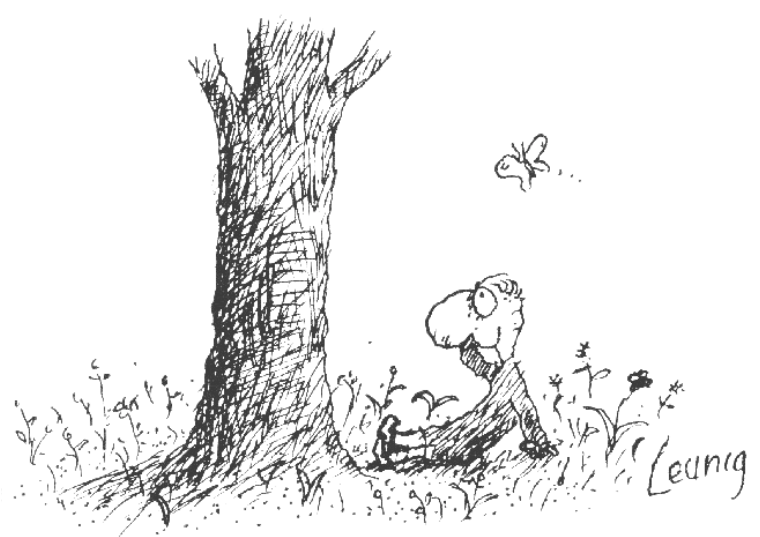
distance education suggests no significant differences in outcomes between classroom and distance learning (Russell, 1999), but even if this were true (the book itself 
raises questions about poor research designs), is it enough to justify the costs in dollars, time and stress involved?

This author is optimistic enough to believe that there are good reasons for persevering, especially in environments where excellent infrastructures are provided in any case for information management and communication purposes. The literature suggests that students do not resent online learning (Myth 5) when they are involved in quality offerings (Felix, 2001, Fountain \& Thomson, 2001, Johnson et al, 2001). There is also some evidence that they may change their minds about possible original negative judgments once they have experienced new additions to their learning environment such as participation in well monitored discussion groups (Fountain \& Thomson, 2001:60):

One could miss an opportunity for exciting web-based engagement by

following too closely the preferences of students.

While there is no doubt that poor teaching exists online, there is no reason to believe that it is impossible to teach well online (Myth 6). On the contrary there is ample proof that excellent teaching is being carried out using the Web and the Internet in a variety of creative ways (Warschauer, 1995, 1996, Warschauer \& Kern, 2000, White \& Weight, 2000, Felix, 2001). How this might be possible within the major constraints discussed above will be the focus of the next section.

\section{Doing it well within the constraints: Seeing the wood and the trees}

In any environment the secret to minimising frustration and stress lies in the ability to judge clearly the goals against the constraints of the local context and not to attempt the impossible. It is often surprising how effective even the simplest application can be in language learning, and it is not without reason that some software companies still sell the most primitive programs because they

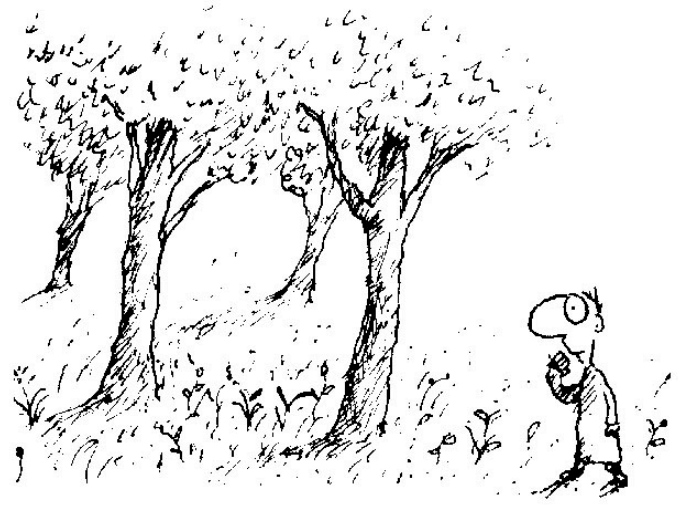
are seen as both useful 
and user friendly. In this section we will investigate how teachers with varying levels of expertise and resources might exploit the new technologies for sound pedagogical purposes. The bulk of the discussion deals with additions to face to face teaching in ascending order of sophistication, culminating in a brief examination of what would be required to offer a quality language course fully online.

In terms of approach we adopt a socio-cognitive, constructivist perspective, not only because current best teaching practice tends in this direction, emphasising dynamic, situated learning environments in which knowledge and the conditions under which it is constructed are inextricably linked (Hannafin, 1997), but more importantly because it is becoming evident that this is where the new technologies have the most to contribute (Debski, 1997, Kern \& Warschauer, 2000, Steeples \& Jones, 2002). Interestingly, the new learning approaches share three characteristics with the originators of communicative approaches to language teaching - namely, that tasks have to be contextualised, authentic, and meaningful to the student. They also sit well with Halliday's emphasis on the interpersonal function of language use in language teaching activities (see Kern \& Warschauer, 2000:5). In sharp contrast to Noble's view above, we will demonstrate that

...the technology is not just a machine, or even just the use of a machine, but rather a broad form of social organization. (Kern \& Warschauer, 2000:15)

\section{Some prerequisites}

In any context a few prerequisites need to be considered if constraints are to be minimised and quality outcomes achieved. Firstly, it is most important that all resources and technologies are tested in situ, and that only stable and user friendly sites are considered for use by students. It goes without saying that nothing can be attempted without reliable Internet access. Secondly, set tasks need to be matched to students' abilities and metaskills - some training may be required here in terms of learning how to learn. It may be useful to involve students in negotiating tasks in order to address different learning styles, strategies and interests. Thirdly, objectives need to be clear, activities fully integrated into the students' regular curricula and work recognised with appropriate, timely and meaningful feedback. Fourthly, students need to be given clear guidelines as to how much access to their tutor is regarded as reasonable. Lastly but most importantly, technology should not be used gratuitously, i.e. simply because it is there. In fact, technology should be in the background, with the focus firmly on learning. If an activity can be carried out or an objective reached equally well without it, there is no justification for the added expense and potential frustrations discussed above. 


\section{Additions to face to face teaching}

At the most simple level creative teachers have access to a plethora of ready made resources free of charge (Felix, 2001), requiring no more than simple word processing and Web searching skills, and the ability to use email. The most interesting of these are task based activities, such as the excellent collection for German, housed on the AATG site; Webquests of various forms, including online travel simulations (Travelsim) and email quests such as Odyssee. All of these have the potential to engage students either singly or in groups in authentic settings in which to foster one or more language skills, depending on how activities are structured, integrated and monitored. Like any teaching resource, these can be regarded as part of the teacher's toolkit, which in itself will only ever be as exciting as the teachers' and students' imaginations, enthusiasm and dedication. What may look fairly uninteresting to some may well be brought to excellent use by others. Eliza is a fine example here (Figure 1).

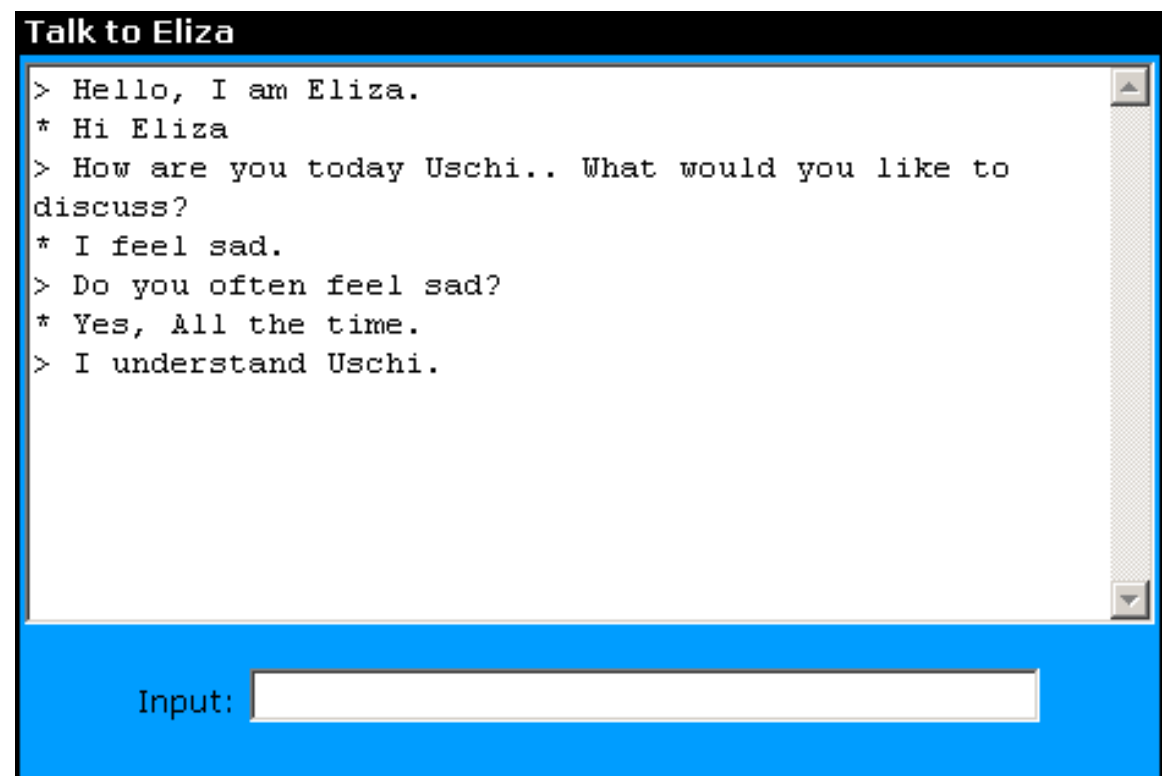

Figure 1. Eliza

Originally created as a simulation of a session with a psychotherapist, this most unassuming looking tool, with pseudo artificial intelligence capabilities, could be used most creatively by setting up a competition for creating the most plausible dialogue with whomever they wish Eliza to represent. This would engage students in a multitude of information gap attempts at different levels of discourse, analysing structures and 
semantics in a meaningful context, and producing a piece of written dialogue as a tangible goal with the added bonus of winning a prize. Students with high level computer skills could even prepare their own versions of these programs as personalised bots (see Chatterbox for examples of bots and dialogues). The attractive bonus for the teacher consists of the uneven distribution between minimal preparation time, maximum engagement of students and potentially worthwhile outcomes.

Infrastructures for all of these activities exist in most Western educational institutions now, and time commitment is relatively low, especially when we consider that language teaching has always been a time consuming activity, usually carried out by remarkably dedicated and hard working professionals, in any case engaged in producing elaborate materials and setting up simulated real life environments. Using existing materials, teachers will save on the time they would otherwise spend preparing course materials, but they will also have to invest time in assisting in the organisation of tasks, moderating email communications, and creating sound feedback strategies. This is certainly not a saving of time but the redistribution of time may well bear fruit in a richer, more empowering and more authentic learning environment for the students.

At a medium level of sophistication teachers are currently using threaded discussion groups and user friendly chats and MOOs based in the target language countries. A potential problem here is the intrusion of unwanted participants in authentic asynchronous and synchronous environments. A wonderful chat site like dubit (Figure 2), which includes excellent graphics and entertaining games, for instance, invariably includes offensive or unwanted participants. Rather than resorting to less motivating standard chats provided in course tools such as WebCT, a private channel might be negotiated with the developers - in the case of dubit a group of young student enthusiasts. MOOs and chats specially designed for language teaching are always safe options, but the price to pay is authenticity.

Teachers with moderate Web development skills might consider giving their students the task of translating a program such as Eliza. Java scripts can be downloaded from the site, and the language items and registers can be varied from fairly simple to highly sophisticated. (The author herself has translated this program into French and German with minimal technical support.) This could be a motivating cooperative project with a tangible and reusable product as an additional outcome to the language that might be learnt in the process. Other collaborative ventures gaining popularity at this level are students producing their own Websites around topics of interest, as alternatives to traditional assignments. Again, these could be used as teaching resources with different groups and in other settings. What needs to be considered here, of course, is that assessment of 
these types of activities has to match the process (see Laurier, 2000 on authentic assessment).

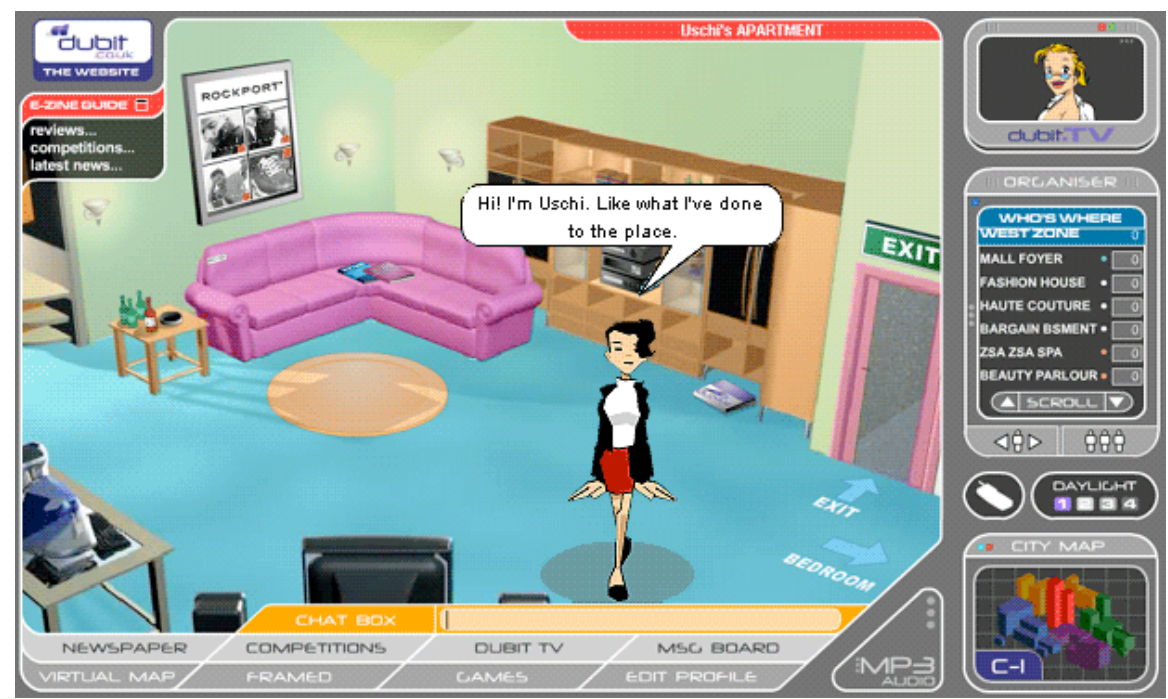

Figure 2. Dubit

At this level dedicated teachers have also begun creating their own modest resources using free tools and templates such as the popular Hot Potatoes and Quia. While this has produced a large bank of interesting materials, including instant feedback, there are two problems with this approach. The first is that it is very easy to return to a drill and practice paradigm and transmission model when using a standard template approach. This might be partially overcome by involving the students in the production of the exercises. The second problem is that resources are being duplicated at mind boggling rates, especially in the major world languages. How we might address this very common problem will be discussed below.

At the highest level of sophistication teachers are beginning to integrate voiced threaded bulletin boards such as Wimba and voiced chats such as Traveler which have the capacity to engage students in motivating oral activities, as well as providing avenues for personalised feedback. Disappointingly, though, what is currently found on the Wimba site is no different from what is possible with simple audiotape technology or what can be done by phone, a clear example of entrenched drill and practice pedagogy when the technology itself offers so much more. The most creative use of Wimba would be for problem solving and information gap activities, involving the students in planting and retrieving oral cues in the 
process of solving mysteries such as those reported by Nelson \& Oliver (1999), or engaging in quests along the lines of Odyssee.

Teachers at this level are also increasingly engaged in producing extensive Web resources of various kinds, ranging from interactive online grammar books to involving students in sophisticated collaborative ventures using email, video conferencing and virtual worlds (see Söntgens, 2000, Zähner et al, 2000, Felix, 2001). Activities here are usually funded by special grants, which might cover the cost of software licences or fund some time release. While many excellent models exist, especially those using the Active Worlds software (Fig. 3), two problems can be identified. The first is that projects often do not survive beyond the time funding was available there are numerous sites which have not been updated for years. The second is the one mentioned above - duplication of effort is taking place at all levels.

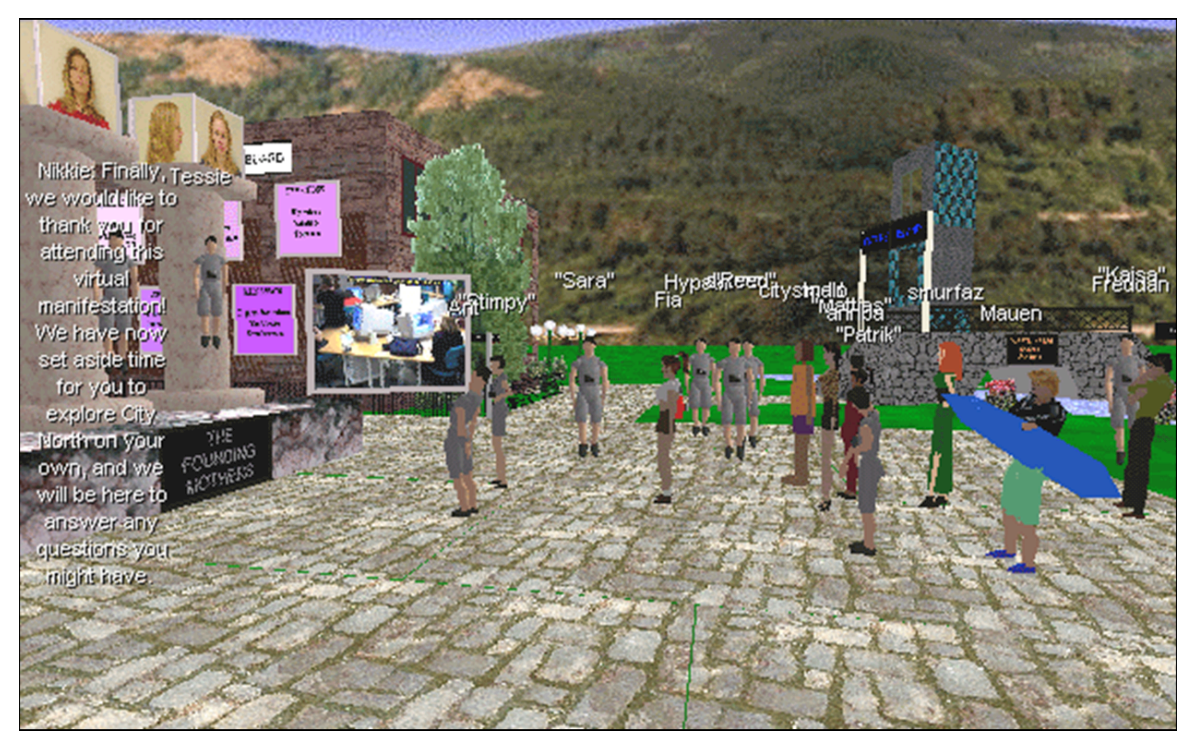

Figure 3. Active Worlds

So much in the way of time and resources is invested and sometimes wasted in these activities that the time has come to think seriously about global co-operation, with the goal to produce a repository of reusable or tradable learning objects (Ip \& Morrison, 2001, Oliver, 2001, Boyle \& Cook, 2001). Ideally each particular object would contain metadata relating to content and pedagogical approach that would allow easy retrieval through a data base (see SCORM and Dublin Core Metadata sites). Of course this is much easier said than done. Common obstacles are the still 
entrenched not developed here syndrome, resistance to standards, copyright problems, difficulties with credit procedures, and the fact that institutions compete with each other rather than share and cooperate. Nevertheless, the debate is taking on momentum in education in general with a focus on world wide standards in the development of online teaching resources (see IEEE site), and a number of projects applying the idea are under way world-wide (see MERLOT, SoURCE, PROMETEUS sites). In online language offerings we have made small inroads into sharing resources through initiatives such as WELL and metasites and consortia (see Felix 2001), but we still have a long way to go to reach the goal of true interoperability of resources. Delcloque's (2001:74) observation in the context of the DISSEMINATE project is absolutely crucial for success:

...we must share and build on our knowledge and work collaboratively to facilitate the ownership of tools with built-in flexibility instead of inbuilt obsolescence.

\section{Stand-alone online courses}

There have to be good reasons for taking on the challenge of developing fully-fledged online language courses. Teaching a language is already a complex and demanding enterprise in the classroom. Doing it fully online adds a dimension which leaves no room for the compromises in terms of infrastructure, resources, expertise, support and prerequisites discussed earlier. This is not the territory for the one-person enthusiast, although some excellent examples exist where teachers have dedicated their entire professional life to this challenge (see Cyberitalian). Generally it is best handled on an institutional level where a team of educational designer, programmer, content provider, graphic designer and online tutors can work together to develop a course that will stand up to scrutiny not only in terms of pedagogy and design but most importantly in terms of quality outcomes. Although here, too, consideration needs to be given to not reinventing the wheel by incorporating existing resources and developing tradable learning objects.

Current stand-alone language learning programs have improved tremendously over the last two years, especially through the recognition of the value of constructivist approaches in this environment, and increased interactivity on the whole. Large commercial enterprises such as Global English have invested heavily in interactivity online, always at the cutting edge of technology (including voice-recognition software) and employing 24-hour tutor support through a chat site. Generally, though, three important elements are still handled poorly in such offerings. These are providing personalised and meaningful feedback, creating a sense of community and belonging, and catering for the development of oral language 
skills. As we have seen above, the latest technologies offer the potential to overcome these difficulties, but the challenge lies in exploiting their potential to the full. Apart from investing in the best technologies and support structures, we need to find ways of personalising and humanising online learning in a systematic and holistic manner, that will permeate the total student experience. How this may be achieved will be discussed in more detail in a forthcoming publication (Felix, in press).

Ultimately, the information revolution is not about technology; it is about what happens to people as a result. We have to remember that education is a very human endeavor and that students are terribly important people. Although technology plays a central role, people still come first. (Morrison \& Oblinger, 2002:5)

\section{Conclusion}

Providing quality online learning opportunities requires a high level of commitment on the part of all three groups involved in the process. Administrators need to invest in excellent infrastructures and support, teachers need to find ways of incorporating the unique potential of the new technologies into an enriched curriculum, and students need to be open to new forms of constructing knowledge far beyond traditional expectations, contributing to both the process and the goals. That costs can be saved in this ambitious enterprise is clearly a myth, as are expectations of saving time or replacing staff with machines.

Equally in the realm of myth can be placed the assertion that students resent online learning outright and that online teaching must be inferior to face to face instruction. On the contrary, there is ample evidence that the most significant educational contribution of the new technologies lies in the opportunities for adding quality to what has always been difficult to achieve in the language classroom: facilitating interpersonal communication in authentic settings, sustaining meaningful information gap activities, and involving students in creative problem based and project based learning with native speaker partners. It is important, though, not to get carried away with the promise but to evaluate clearly the outcomes against the effort and the goals against the constraints. Most of all, in an environment where cost and time are still the greatest obstacles to success (Morrison \& Oblinger, 2002), we need to think seriously about sharing resources rather than duplicating efforts.

\section{Acknowledgment}

Many thanks to Michael Leunig and Penguin Books for their kind permission to include the four Leunig cartoons. 
An earlier version of this paper was delivered as keynote address at the Setting the Agenda. Languages, Linguistics and Area Studies in Higher Education Conference, Manchester, UK, 2002

\section{References}

Bacsich, P., Ash, C. \& Heginbotham, S. (2001). The cost of networked learning Phase Two. [verified 19 Feb 2003] http:/ / www.shu.ac.uk/cnl/

Berge, Z.L. (1995). The role of the Online Instructor/Facilitator. http: / / jan.ucc.nau.edu/ mpc3 / moderate/teach_online.htm [not found 19 Feb 2003, see http: / / www.emoderators.com/moderators/teach_online.html]

Boyle, T., \& Cook, J. (2001). Towards a pedagogically sound basis for learning object portability and re-use. Conference Proceedings, ASCILITE'01: Meeting at the Crossroads, Melbourne, Victoria, 101-109. [verified 19 Feb 2003] http: / / www.ascilite.org.au/conferences/melbourne01/pdf/papers/boylet.pdf

Brabazon, T. (2001). Internet teaching and the administration of knowledge. http:/ / www.firstmonday.org/issues/issue6_6/brabazon/index.html

Cho, S.K. \& Berge, Z. (2002). Overcoming barriers to distance training and education. http:/ / www.usdla.org/html/journal/JAN02_Issue/article01.html

Darby, J. (2002). Networked learning in higher education: The Mule in the barn. In C. Steeples \& C. Jones (Eds.), Networked Learning: Perspectives and Issues, 17-26, London: Springer.

Davies, G. (2002), ICT and modern foreign languages: Learning opportunities and training needs. In press: Cuadernos de flilologia inglesa (11) 1: Monograph issue, New trends in computer Assisted Language Teaching/Learning, Servicio de publicaciones, Universidad de Murcia, Spain.

DeFerrari, C., Dozier, D., Klubeck, J. \& Real, M., (1998). Learning out of the box: Perceived relative advantages of on-line distance learning against the norm. [verified 19 Feb 2003] http:/ / www.cdfmedia.com/learning.html

Debski, R. (1997). Support of creativity and collaboration in the language classroom: a new role for technology. In R. Debski, J. Gassin \& S. Smith (Eds.), Language learning through social computing 39-66. Occasional Papers Number 16, Melbourne: ALAA and the Horwood Language Centre.

Delcloque, P. (2001). DISSEMINATE or not? Should we pursue a new direction: Looking for the "third way" in CALL development? In A. Chambers \& G. Davies (Eds.), ICT and language learning: A European perspective, Lisse: Swets \& Zeitlinger.

Felix, U. (2000). The potential of CD-ROM technology for integrating language and literature: student perceptions. http: / / www.gfl-journal.de/2-2000 / felix.pdf

Felix, U. (2001). Beyond Babel: Language Learning Online. Melbourne: Language Australia. 
Felix, U. (2002). The web as vehicle for constructivist approaches in language teaching. Recall, 14 (1), 2-16.

Felix, U (in press). Language Learning Online: Towards Best Practice. Lisse, Swets \& Zeitlinger.

Fountain, W. \& Thomson, S. (2001). Backyard wisdom and student insights in developing effective web-supported learning. Conference Proceedings (Short papers), ASCILITE'01: Meeting at the Crossroads, Melbourne, Victoria, 57-60. http:/ / www.ascilite.org.au/conferences/melbourne01/pdf/papers/fountainw.pdf

Goodyear, P. (2002). Psychological foundations for networked learning. In C. Steeples, \& C. Jones (Eds.), Networked Learning: Perspectives and Issues, 49-75. London: Springer.

Hannafin M.J. (1997), The case for grounded learning systems design: What the literature suggests about effective teaching, learning, and technology. Conference Proceedings, ASCILITE 1997, Perth, Western Australia, 255-262. http: / / www.ascilite.org.au/conferences/perth97/ papers/Hannafink/Hannafink.html

Hara, N. \& Kling, R. (1999). Students' frustrations with a Web-based distance education course. http:/ / firstmonday.org/issues / issue4_12/hara/index.html

Hargittai, E. (2002). Second-level digital divide: Differences in people's online skills. First Monday, 7(4), 1-19. http:/ / firstmonday.org/issues/issue7_4/hargittai/index.html

Ip, A. \& Morrison, I., (2001). Learning objects in different pedagogical paradigms. Conference Proceedings, ASCILITE'01: Meeting at the Crossroads, Melbourne, Victoria, 289-298. http: / / www.ascilite.org.au/conferences / melbourne01/pdf/papers/ipa.pdf

Johnson, E.M., Bishop, A., Holt, A., Stirling, J. and Zane, J. (2001). Reflections in cyberspace: Web conferencing for language teacher education. Australian Journal of Educational Technology, 17 (2), 169-168. http: / / www.ascilite.org.au/ajet/ajet17/johnson.html

Kern, R. \& Warschauer, M. (Eds.) (2000). Introduction: Theory and practice of network-based language teaching. In M. Warschauer \& R. Kern (Eds), Networkbased Language Teaching: Concepts and Practice. Cambridge: Cambridge University Press, 1-19.

Kirkman, G. S. (Ed.) (2002). Global Information Technology Report 2001-2002: Readiness for the Networked World. Oxford: Oxford University Press.

Laurier, M. (2000). Can computerised testing be authentic? ReCALL, 12 (1), 93-104.

Leunig, M. (1995). You and Me. Melbourne: Penguin Books.

Mackay, H. (2001). Education in hyperspace: When will we ever learn? The Age, February 3. 
Morgan, C. (2001), Seeking Perseverance Through Closer Relations with Remote Students. Conference Proceedings (short papers), ASCILITE'01: Meeting at the Crossroads, Melbourne, Victoria, 125-128.

http:/ / www.ascilite.org.au/conferences/melbourne01/pdf/papers/morganc.pdf

Morrison, J. \& Oblinger, D. (2002). Information technology and the future of education: An interview with Diana Oblinger. [verified 19 Feb 2003\} http: / / ts.mivu.org/default.asp?show=article\&id=983

Nelson, T. \& Oliver, W. (1999). Murder on the Internet. CALICO, 17(1), 101-114.

Noble, D.F (1997). Digital Diploma Mills, part I, The automation of higher education. http: / / communication.ucsd.edu/dl/ddm1.html

Noble, D.F. (1998a). Digital Diploma Mills, part II, The coming battle over online instruction. http:/ / communication.ucsd.edu/dl/ddm2.html

Noble, D.F. (1998b). Digital Diploma Mills, part III, The bloom is off the rose. http: / / communication.ucsd.edu / dl/ddm3.html

Noble (2001). Personal interview on ABC Radio National broadcast. http: / / abc.net.au/rn/talks/bbing/mod/bbing_20012002_2856.ram

Oliver, R. (2001). Seeking best practice in online learning: Flexible learning toolboxes in the Australian VET sector. Australian Journal of Educational Technology, 17(2), 204-222. http: / / www.ascilite.org.au/ajet/ajet17/oliver.html

Rocklin, T. (2001). Do I dare? Is it prudent? National Teaching and Learning Forum Newsletter, 10(3), Oryx Press.

Russell, T.L. (1999). The No Significant Difference Phenomenon. Chapel Hill, NC: Office of Instructional Telecommunications, North Carolina University.

Salmon, G. (2000). E-moderating: The key to teaching and learning online. London: Kogan Page

Schanck, R. \& Cleave, J. (1995). Natural learning, natural teaching: Changing human memory. In H. Morowitz \& J. Singer (Eds.), The mind, the brain and complex, adaptive systems, 175-202. Reading, MA: Addison-Wesley.

Söntgens, K. (2000). Circling the globe: Fostering experiential language learning. ReCALL, 13, 59-66.

Steeples, C. \& Jones, C. (Eds.) (2002). Networked learning: Perspectives and issues. London: Springer.

Stott, C. (1999). High-Tech Heretic. New York: Anchor Books

The Campus Computing Project, October 1999 - The Continuing Challenge of Instructional Integration and User Support. [verified 19 Feb 2003] http: / / www.campuscomputing.net/summaries/1999/index.html 
Tuovinen, J. (2001). Finnish Virtual (Online) Collaborative University - A Model for Australia. Conference Proceedings, ASCILITE'01: Meeting at the Crossroads, Melbourne, Victoria, 529-538.

http:/ / www.ascilite.org.au/conferences/melbourne01/pdf/papers/tuovinenj.pdf

Walker, D. (2002), Computing the costs in dollars and stress. The Age, Melbourne, 26.2. 2002.

Warschauer, M. (1995). Virtual Connections: Online Activities \& Projects for Networking Language Learners. Hawaii: University of Hawaii Press.

Warschauer, M. (1996). Computer-mediated Collaborative Learning: Theory and Practice. Modern Language Journal, 18 (4), 470-481.

Warschauer, M. \& Kern, R. (Eds.), (2000). Network-based Language Teaching: Concepts and Practice. Cambridge: Cambridge University Press.

Weight, B. \& Bishop, T. (2000). Epilogue: The human practice. In K. White \& B. Weight, The Online teaching guide 183-188, Boston: Allyn and Bacon.

White, K. \& Weight, B. (2000). The Online teaching guide. Boston: Allyn and Bacon.

Zähner, C., Fauverge, A. \& Wong, J. (2000). Task-based language learning via audiovisual networks: The LEVERAGE project. In M. Warschauer \& R. Kern (Eds.), Network-based Language Teaching: Concepts and Practice 186-203, Cambridge: Cambridge University Press.

Websites [verified 19 Feb 2003]

Active Worlds. http: / / www.activeworlds.com/

American Association of Teachers of German (AATG)

http:/ / grow.aatg.org/vol_1-3/web_activities/index.html

Chatterbox http: / / www.frontiernet.net/ wcowart/ contest_links.html [not found 19 Feb 2003]

Cyberitalian http: / / cyberitalian.com/

Dublin Core Metatdata Initiative http:/ / www.dublincore.org /

Dubit www.dubit.co.uk

Eliza http: / / www.manifestation.com/neurotoys/eliza.php3

Global English http:/ / www.globalenglish.com/

Hot Potatoes http:/ / web.uvic.ca/hrd/halfbaked/

IEEE http:/ / ltsc.ieee.org/

MERLOT http:/ / taste.merlot.org/

Quia http:/ / www.quia.com/ 
Odyssee http: / / www.goethe.de/oe/mos/odyssee/ deindex.htm

PROMETEUS http:/ / www.prometeus.org/

Shareable Content Object Reference Model (SCORM) http: / www.adlnet.org

SoURCE http: / / www.source.ac.uk/

Traveler http: / / www.digitalspace.com/traveler /

Travelsim http: / / deil.lang.uiuc.edu/travelsim /

WebCT http: / / webct.com/

Wimba http:/ / www.wimba.com/

Professor Uschi Felix

Director ArtsIT and Associate Dean (Information Technologies)

Faculty of Arts, Monash University, Clayton Vic 3800, Australia

Email: uschi.felix@arts.monash.edu.au

http: / / www-personal.monash.edu.au/ ufelix / index.htm 